\title{
Solid oxide fuel cells powered by biomass gasification for high efficiency power generation
}

Gadsbøll, Rasmus Østergaard; Thomsen, Jesper; Bang-Møller, Christian; Ahrenfeldt, Jesper; Henriksen, Ulrik Birk

\section{Published in:}

Energy

Link to article, DOI:

10.1016/j.energy.2017.05.044

Publication date:

2017

Document Version

Peer reviewed version

Link back to DTU Orbit

Citation (APA):

Gadsbøll, R. Ø., Thomsen, J., Bang-Møller, C., Ahrenfeldt, J., \& Henriksen, U. B. (2017). Solid oxide fuel cells powered by biomass gasification for high efficiency power generation. Energy, 131, 198-206.

https://doi.org/10.1016/j.energy.2017.05.044

\section{General rights}

Copyright and moral rights for the publications made accessible in the public portal are retained by the authors and/or other copyright owners and it is a condition of accessing publications that users recognise and abide by the legal requirements associated with these rights.

- Users may download and print one copy of any publication from the public portal for the purpose of private study or research.

- You may not further distribute the material or use it for any profit-making activity or commercial gain

- You may freely distribute the URL identifying the publication in the public portal 


\section{Accepted Manuscript}

Solid oxide fuel cells powered by biomass gasification for high efficiency power generation

Rasmus Østergaard Gadsbøll, Jesper Thomsen, Christian Bang-Møller, Jesper

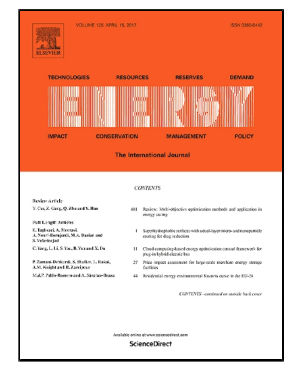
Ahrenfeldt, Ulrik Birk Henriksen

PII: S0360-5442(17)30801-0

DOI: 10.1016/j.energy.2017.05.044

Reference: EGY 10851

To appear in:

Energy

Received Date:

02 February 2017

Revised Date:

05 May 2017

Accepted Date:

07 May 2017

Please cite this article as: Rasmus Østergaard Gadsbøll, Jesper Thomsen, Christian Bang-Møller, Jesper Ahrenfeldt, Ulrik Birk Henriksen, Solid oxide fuel cells powered by biomass gasification for high efficiency power generation, Energy (2017), doi: 10.1016/j.energy.2017.05.044

This is a PDF file of an unedited manuscript that has been accepted for publication. As a service to our customers we are providing this early version of the manuscript. The manuscript will undergo copyediting, typesetting, and review of the resulting proof before it is published in its final form. Please note that during the production process errors may be discovered which could affect the content, and all legal disclaimers that apply to the journal pertain. 
Highlights of the article " Solid oxide fuel cells powered by biomass gasification for high efficiency power generation"

- Design and operation of a gasification-SOFC system with minimal gas cleaning

- Experimental results from full load, part load and long-term tests with product gas

- Electric efficiencies around $40 \%$ biomass-to-power for small-scale power generation

- Modeled gasification-SOFC combined cycle concepts with efficiencies up to $62 \%$ 


\section{$1 \quad$ Solid oxide fuel cells powered by biomass gasification for high}

3

\section{efficiency power generation}

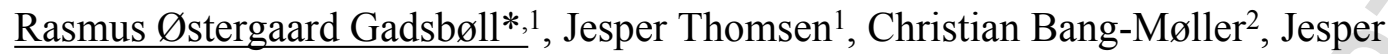

\section{Ahrenfeldt ${ }^{1}$ Ulrik Birk Henriksen ${ }^{1}$}

Technical university of Denmark, Department of chemical and biochemical engineering, Frederiksborgvej 399, 4000 Roskilde, Denmark

${ }^{2}$ Haldor Topsoe A/S, Haldor Topsøes allé 1, 2800 Kgs. Lyngby, Denmark

*Corresponding author, Tel: +4560668815, E-mail: rgad@kt.dtu.dk

\section{ABSTRACT}

Increased use of bioenergy is a very cost-effective and flexible measure to limit changes in the climate and the infrastructure. One of the key technologies toward a higher implementation of biomass is thermal gasification, which enables a wide span of downstream applications. In order to improve efficiencies, flexibility and possibly costs of current biomass power generating systems, a power plant concept combining solid oxide fuel cells (SOFC) and gasification is investigated experimentally. The aim of the study is to examine the commercial operation system potential of these two technologies. Investigations are done by combining the commercial TwoStage Viking gasifier developed at the Technical University of Denmark and a state-of-the-art SOFC stack from Topsoe Fuel Cell for high efficiency power generation. A total of 5 tests were performed including polarization tests at various gas flows to study part-load operation; and a longer test to investigate stability. The study shows experimentally the potential and feasibility of a SOFC-gasification system with a commercial gasifier and a SOFC stack by measuring the highest reported values of such a system, with biomass-to-electricity efficiencies up to $43 \%$. Results from related modeling studies are also 
presented, showcasing the intriguing potential of the system with modeled cycle electric efficiencies up to $62 \%$.

Keywords: Bioenergy, Biomass, Gasification, Fuel cell, SOFC, Power generation

\section{INTRODUCTION}

The most cost-effective path to reduce climate change is through increasing the share of bioenergy significantly, because biomass to a large extent can directly substitute fossil fuels in the present infrastructure $[1,2,3]$. Currently, biomass is mainly utilized as a substitute to fossil fuels in large $\left(>50 \mathrm{MW}_{\text {th }}\right)$, efficient, and modern steam power plants that reach electric efficiencies up to about $40-50 \%$ [1]. However, such plants are limited to high capacities, if high efficiencies are to be maintained. In smaller typical biomass power plants $\left(10-50 \mathrm{MW}_{\mathrm{th}}\right)$ electrical efficiencies drop to $18-33 \%$ and will require flexible operation on cheap, local feedstock to be competitive in the future [1]. So, the future energy system will require advanced biomass conversion and power generating technologies to ensure environmental as well as economic sustainability.

Solid oxide fuel cell (SOFC) technology is an interesting option for high-efficient power generation in future energy systems. SOFC technology is currently under extensive research as one of the most promising near-future power technologies. Fuel cells convert gaseous chemical energy directly into electric energy through electrochemical reactions and are thus subject to less loss than traditional power generation technologies. The SOFC's are especially interesting for smaller scale power systems, as they offer high fuel flexibility $\left(\mathrm{CO}, \mathrm{H}_{2}, \mathrm{CH}_{4}\right)$, compared to other fuel cell types and can maintain their very high electric efficiency at smaller scales and part load operation. The high operating temperatures of $700-900^{\circ} \mathrm{C}$ in the SOFC allows internal reforming of e.g. hydrocarbons in the stack, which increases its fuel flexibility greatly. SOFC operation is however limited by its nickel containing anode, which 
requires a reducing atmosphere to stay active and forces the fuel cell to exhaust excess fuel.

The fraction of fuel used is called the fuel utilisation (FU).

In order to utilize biomass as a fuel for fuel cells, a conversion from solid to gaseous fuel is required, this can be achieved via gasification. At high temperatures, thermal gasification offers a very flexible and highly efficient platform to convert solid carbonaceous matter into a combustible product gas. This gas typically consists of lower hydrocarbons, $\mathrm{CO}, \mathrm{CO}_{2}, \mathrm{H}_{2}, \mathrm{~N}_{2}$, inorganic impurities and tars. State-of-the-art gasification plants reach cold gas efficiencies of 80-93\% (biomass to product gas [LHV]) [4]. The produced gas can afterwards be processed for a variety of applications including power, heat, chemical and fuel production applications. As a joint technology platform, SOFC-gasification systems that combine the fuel flexibility and conversion efficiency of gasification and the high electric efficiency of fuel cell technology have very high potential. Recent modeling studies from the Bio-SOFC project have shown that SOFC-gasification systems can reach electric efficiencies of $42-62 \%$ with proper design - see e.g. [5,6,7]. However, product gas quality and capital costs pose a challenge to further development and commercialization [8]. Product gas quality relates specifically to tars, inorganics, and particulates that can terminate fuel cell operation and thus strict gas conditioning is typically required.

SOFC-gasification systems are still on the laboratory scale and limited tests have been performed on real product gas from a gasifier $[9,10,11,12,13,14]$. In addition, most of these tests have only been on single cells, at low loads and/or for short time periods. The focus of these studies has mostly been on gas quality. Hofmann et al. $[9,10,11]$ and Jewulski et al. [12] discussed and tested internal reforming of tars and lower hydrocarbons in the SOFC, and concluded that these compounds can be utilized as a component in the fuel if sufficient steam is added to the gas stream to avoid carbon deposition. Tests with product gas above $10 \mathrm{~g} / \mathrm{nm}^{3}$ 
of tars from a circulating fluid bed were found to be feasible at low loads [11] and tests with product gas from an updraft gasifier showed tolerance to tars up to $85 \mathrm{~g} / \mathrm{nm}^{3}$ at low loads [14]. While product gas with no tars, low levels of steam and light hydrocarbon levels above 9 vol\% caused carbon deposition and mechanical fracture as a result of internal endothermic reforming reactions [12]. Caution should be taken when evaluating tar concentrations, as both composition and concentration will depend on the gasifier design and applied conditions. SOFC operating on product gas at high load (fuel utilization of $>70 \%$ ) have shown high electric efficiencies of up to $38 \%[10,13]$. Hofmann et al. [10] operated a downdraft gasifier with low tar levels $\left(<0.2 \mathrm{~g} / \mathrm{nm}^{3}\right)$, but found that the high load caused anode oxidation. Oudhuis et al. [13] employed a pyrolyzer with extensive gas cleaning and thus obtained a clean gas that proved stable operation with the SOFC.

As mentioned, studies of SOFC-gasification systems are mainly focus on gas quality investigations and do therefore not represent a commercially operating system. Such a system will be operated at high loads, at various gas flow rates, and with limited gas cleaning to lower costs. Also, the gasifier will have to be very efficient in retaining as much of the chemical energy in the solid fuel into gas with a high cold gas efficiency, as the chemical energy is a main bottleneck for electrochemical combustion.

The TwoStage biomass gasifier at the Technical University of Denmark are a proven and commercial gasification system that can achieve a very high cold gas efficiency of $93 \%$, while producing only an insignificant amount of tars and around 1vol\% light hydrocarbons (methane) with only a bag filter for gas cleaning [15][16][17]. Given the challenges of the previous cited works within SOFC's with product gas, it is expected that the proposed system will provide a clean gas that will minimize risk of carbon deposition and be technically feasible on commercial terms, including a relatively low level of complexity. Therefore it is 
expected that the coupling of the TwoStage gasifier and a state-of-the-art fuel cell stack will provide a system that will move the joint technology platform closer to commercialization and feature: 1) very high electric efficiency; 2) low levels of gas cleaning; 3) stable operation.

In 2007, the TwoStage gasifier was operated with a single-cell SOFC continuously for 150 hours at low load and showed potential for stable operation [9]. This project continues the investigations previously started in [9] and will investigate commercial terms of operation. The current study operates an $800 \mathrm{~W}_{\mathrm{e}}$ state-of-the-art SOFC stack at high load on real product gas from the TwoStage gasifier. Specifically, this study examines the full- and part-load performance of the stack when varying flow rates and load and performs long-term tests of the stack at high load. The study shows experimentally the potential and feasibility of a SOFC-gasification system with a commercial gasifier and a SOFC stack, coupled using only a bag filter, activated carbon filter, a humidifier, and a desulphuriser.

\section{MATERIALS AND METHODS}

The study was carried out at the facilities at the Technical University of Denmark (DTU), Risø Campus. The experimental equipment included the TwoStage 'Viking' gasifier, necessary fuel cell gas conditioning and the SOFC stack.

\subsection{TwoStage gasifier}

The TwoStage gasification concept has been developed at DTU over several decades and it has been upscaled several times and commercially up to $1.5 \mathrm{MW}_{\text {th }}[15]$. The gasifier is a staged downdraft concept, where the pyrolysis and gasification are carried out in separate reactors with a partial combustion zone in between. The gasifier is unique in its ability to produce gas with virtually no tars $\left(<1 \mathrm{mg} / \mathrm{nm}^{3}\right)$, using only a simple bag house filter and while still obtaining a high cold gas efficiency of $93 \%$ [16]. The applied TwoStage gasifier plant is a 
$80 \mathrm{~kW}_{\text {th }}$ Viking plant, which is fully automated, have been operated for more than 3000 hours and have shown very stable operating characteristics with regards to continuous operation, gas composition and engine operation [17].

A flow diagram of the Viking gasifier is shown in Figure 1. The gasifier is operated at atmospheric pressure levels. Pine wood chips of $\approx 40 \%$ humidity are fed into an externally heated screw conveyor that dries and pyrolyzes the fuel up to $600^{\circ} \mathrm{C}$. No fuel analysis was made, but the fuel is very similar to the fuel used in previous tests, which is shown is Table 1 . The screw conveyor is heated using superheated engine exhaust. The pyrolysis products are led to the second reactor and are partially oxidized by air, raising the temperature above $1100^{\circ} \mathrm{C}$. Hereby, the tar content is reduced by $99 \%$. The gas and char then pass through a hot fixed char bed, where the char is gasified and the temperature is subsequently lowered to $800^{\circ} \mathrm{C}$ at the bed outlet. The hot char bed acts as a tar cleaning unit, removing $99 \%$ of the remaining tars $[17,18]$, yielding a near tar-free gas. The obtained product gas then flows through a series of heat exchangers and a bag house filter that removes small amounts of particles, tars and water. Afterwards, the gas enters a mixing tank, where a slipstream of about $2 \mathrm{~kW}_{\text {th }}$ was directed to the fuel cell setup.

\subsection{Fuel cell gas conditioning}

Gas conditioning is essential when using fuel cells, as this technology is highly sensitive to several gas components. Levels of hydrocarbons have to be monitored, as they will be reformed internally in the anode and cause thermal stresses by cooling and can cause carbon deposition. The reforming of hydrocarbons needs a sufficient water vapor pressure in order to avoid carbon deposition and thus the gas needs to be humidified. Inorganic compounds, including sulphur, need to be completely removed to avoid anode deactivation.

The product gas initially flowed through two active carbon filters at room temperature with a 
retention time of 53 seconds. These filters act as guard beds, removing inorganic compounds and tars.

Afterwards, the gas passed through an electrically heated water spray tower, where it was humidified to reach an oxygen-carbon molar ratio of 2 . The humidification temperature was $60^{\circ} \mathrm{C}$, which correspond to a water molar fraction of about $19.5 \%$ in the humidified product gas.

The humid product gas was electrically heated to $245^{\circ} \mathrm{C}$ and led through a fixed guard bed with $\mathrm{ZnO}$ pellets that removed remaining sulphur compounds up to $10 \mathrm{ppm}$. Afterwards the gas was heated electrically to $670^{\circ} \mathrm{C}$ before being fed to the SOFC. An overview of the gas conditioning is shown in Figure 2.

The gas composition was measured at dry and tar-free conditions with an Advance Optima 2020 Modular continuous process gas analyzer system, with an Caldos 15 cell for $\mathrm{H}_{2}$ analysis and an Uras 14 cell for $\mathrm{CO}, \mathrm{CO}_{2}$ and $\mathrm{CH}_{4}$ (ABB, Switzerland). The $\mathrm{O}_{2}$ content was measured with an PMA $10 \mathrm{O}_{2}$-analyzer. The uncertainty of the gas analyzer is $\pm 1 \%$ of the measured value. The continuous gas flow for the analyzer system was taken via a twist filter following the carbon filters.

Tars and sulphur compounds were measured at the inlet and outlet of the carbon filters. For tar analysis, solid phase adsorption (SPA) samples were taken during the experimental work with tubes from Supelco with an aminopropyl adsorbent. Three samples were taken before and after the carbon filter. The samples were analysed by gas chromatography/mass spectrometry (GC/MS) with acetone as the solvent with the modification of using stable isotopes of polycyclic aromatic hydrocarbon standards as the internal standards - see further details in reference [17]. Sulphur was measured using $250 \mathrm{~mL}$ gas probes and GC/MS with three measurements before and after the carbon filter. 


\subsection{SOFC stack}

The SOFC stack is produced by Topsoe Fuel Cell. The stack is made of 50 planar, anode supported cells. The anode is made of yttrium-stabilized zirconia (YSZ), nickel catalysts and a mechanical support structure. The electrolyte is made of YSZ and the cathode of lanthanum strontium manganite. The stack is an 'S 1-02' type, with a footprint of $12 \times 12 \mathrm{~cm}$ and a nominal capacity of $800 \mathrm{~W}_{\mathrm{e}}$. It was operated at near atmospheric pressure and the operation was designed for $700^{\circ} \mathrm{C}$ fuel exhaust. The stack was fed with air as oxidizer at $670^{\circ} \mathrm{C}$. The SOFC stack was placed in an electrically heated oven at $700^{\circ} \mathrm{C}$, as the stack was not insulated. The SOFC was heated at $200 \mathrm{~K} / \mathrm{h}$ to minimize thermal stresses. The start-up was carried out at open-circuit conditions with Formier 10 gas $\left(10 \mathrm{v} \% \mathrm{H}_{2}, 90 \mathrm{v} \% \mathrm{~N}_{2}\right)$ and as $700^{\circ} \mathrm{C}$ was reached, the stack was stabilized for $30 \mathrm{~min}$ before switching to product gas. After switching to product gas the SOFC was similarly left for 30min before drawing power from the stack. A picture of the mounted SOFC stack is shown in Figure 3.

\subsection{Experimental procedure}

The experimental work was carried out over 3 campaigns for a total operating time of 145 hours with real product gas as described in [19]. An overview of reported tests is shown in Table 2. Tests started when the SOFC voltage was stabilized after the warm-up (usually after 6 hours). Measurements of voltage, power and gas composition were taken as averages over 3-10 minutes, except values at maximum current that were taken as an average over 60 minutes of operation. National Instruments' LabView 2015 software via a Siemens Step 7 PLC system was used for the data acquisition. 
Flow rates were measured using manual measurements with a flow meter during the tests and are therefore a calculated average value. The SOFC stack load was controlled by increasing the current to specified values on an electric load box. The current was held to a maximum of 25 A, as specified by Topsoe Fuell Cell. During all tests, air was fed non-pressurised at 90 $1 / \min$ (measured at $20^{\circ} \mathrm{C}$ ).

\section{RESULTS AND DISCUSSION}

\subsection{Product gas and SOFC stack temperature}

The product gas was examined three times for tars and sulphur. No tars could be detected using the SPA tar analysis, which is expected as shown in previous campaigns with the gasifier [17]. The SOFC's tolerance towards tars are discussed several places and as mentioned, several tests has been made e.g. [9,10,11]. As rough estimate, Aravind and de Jong [19] gave a threshold value of $2 \mathrm{~g} / \mathrm{Nm}^{3}$ tars in order to avoid carbon deposition, but states that it naturally depends on the tar species, temperature and gas composition. These findings indicate that the TwoStage gasifier design could be altered to reduce the tar conversion, in order to obtain other benefits (e.g. using a smaller char bed/reactor or increasing fuel flexibility by using a fluid bed for char conversion) as a slightly higher tar concentration will not affect the SOFC performance.

Sulphur was analysed for the $\mathrm{COS}$ and $\mathrm{H}_{2} \mathrm{~S}$ compounds, but only $\mathrm{COS}$ could be detected with an average value before the carbon filter of $3.7 \mathrm{ppm}$ and $<0.1 \mathrm{ppm}$ after the carbon filters [20], displaying the relatively simple carbon filters effectiveness. The SOFC's tolerance towards sulphur species is extremely depending on gas composition and temperature, but RostrupNielsen et al. [21] found that a SOFC stack at $800^{\circ} \mathrm{C}$ using partially oxidized jet fuel (gas composition similar to TwoStage product gas) was not affected by 10ppm $\mathrm{H}_{2} \mathrm{~S}$, and while 
$50 \mathrm{ppm}$ decreased performance $10 \%$, the SOFC could easily be regenerated to original performance levels. These findings indicate that the already simple gas condition applied in Figure 2 might be further reduced, so that only the integrated gasifier bag filter (and possibly humidifier depending on the hydrocarbon/tar level) remains upstream of the SOFC, while also allowing the gasifier to increase its tar production if needed.

During the campaigns, only small fluctuations in the product gas composition from the TwoStage gasifier were seen. Average gas compositions during the tests are shown in Table 3. Figure 4 shows as reference, the gas composition fluctuations during Test 5.

Some gas fluctuations were observed during the tests: the bag filter was cleansed and back flushed with nitrogen to reduce pressure drop; and pressure spikes occurred regularly. The pressure spikes occured probably because of water droplet evaporation from the humidifier. Voltages were affected by the pressure increases, resulting in negative spikes until the pressure was reset shortly after - see Figure 8 .

The temperature of the stack increased as the current increased, due to generated waste heat. During Test 5, temperatures were constant as the current was not varied. Results from the measurements of product gas, exhaust gas and air temperatures are shown in Table 4.

\subsection{Performance of SOFC stack}

The performance of the SOFC stack is evaluated based on power output, voltage and electric efficiency (power to fuel input [LHV]). The FU is an appropriate dimensionless base of comparison value across fuel flows and gas compositions. As the FU increases, so does the internal losses in the SOFC, due to mass transfer and concentration losses as the load increases. The FU can be defined using the current, $I$, as the ampere value is a measure of 
conducted electrons (and thus proportional to the number of conducted oxygen-ions). As the steam reforming and water-gas-shift (WGS) reactions by the nickel catalysts at the anode of $\mathrm{CO}$ and $\mathrm{CH} 4$ are faster than the electrochemical reactions [22,23], a molar hydrogen equivalent, $\mathrm{n}_{\mathrm{H} 2 \text {-eq, }}$, is calculated based on complete steam reforming and $\mathrm{WGS}$ of $\mathrm{CO}$ and $\mathrm{CH}_{4}$ , shown in Equation 1. The FU is defined in Equation 2 on a molar basis. $N_{c}$ is the number of cells in the stack and $F$ is Faradays constant.

$n_{H 2-e q}=n_{H 2}+n_{C O}+4 \cdot n_{C H 4}$

$F U=\frac{\frac{I}{2 \cdot F} N_{c}}{n_{H 2-e q}}$

The SOFC performance was tested in a large operating area in order to simulate part- and fullload conditions. Voltage, power density and voltage standard deviation as a function of current density for Test 2 is shown in Figure 5 and the power outputs of the SOFC stack for Test 1-4 are shown in Figure 6. The corresponding electric efficiencies for Test 1-4 are shown in Figure 7. During testing, it was seen that one of the 50 SOFC's in the stack was not producing any power.

Even though the FU was up to $90.2 \%$, there was no significant decline in power in following tests due to internal losses in the stack (see Figure 7) and tests at different flows yielded nearly equal electrical efficiencies across FU. This means that part-load operation down to 55\% flow (Test 1 compared to Test 4) does not reduce the efficiency of the stack, which is an important factor in an energy system with large fluctuations from e.g. wind and solar power. The peak values for Test 1-4 are shown in Table 5, showing the data for the measurements at max FU. The maximum efficiency value (46.4\%), power (875 W) and FU (90.2\%) achieved 
are, to the authors knowledge, the highest values found in literature for product gas operation. These efficiencies are markedly higher than previous tests in which $38 \%$ was reached $[10,13]$. Previous tests with the TwoStage gasifier and a single-cell SOFC showed electric efficiency of $24 \%$ at a fuel utilization of $30 \%$ [9], which is higher than the roughly $18 \%$ obtained here at the same FU. Even though the gas was similar it should be noted that the previous test operated at $850^{\circ} \mathrm{C}$ and a current density of $260 \mathrm{~mA} / \mathrm{cm}^{2}-$ compared to $700^{\circ} \mathrm{C}$ and $\approx 50-100$ $\mathrm{mA} / \mathrm{cm}^{2}$ (depending on test and gas flow). An evaluation of the increased temperature with higher efficiency versus shorter SOFC lifetime should be made when designing such a system.

Considering the gasifier-SOFC system, a plant efficiency $\eta_{\text {plant }}$ can be estimated based on the present results. Using Equation 3, the combinations of SOFC efficiency at maximum FU and gasification efficiency gives TwoStage-SOFC electrical efficiencies of 38-43\%. TwoStage cold gas efficiency is denoted with $\eta_{c g}$ and the SOFC stack efficiency with $\eta_{S O F C}$. The range of this approximation is confirmed through mathematical modeling of the system [24].

$$
\eta_{\text {plant }}=\eta_{c g} \cdot \eta_{S O F C}
$$

The TwoStage-SOFC system is thought as a decentralised constellation in the $<20 \mathrm{MW}_{\text {th }}$ range, as downdraft gasifiers have limitations with regards to scaling [25,26]. The efficiencies of this system are significantly higher than typical competing decentralised biomass power plants at $18-33 \%$ [1]. The obtained efficiencies are comparable with those of biomass power plants with capacities above $100 \mathrm{MW}_{\text {th }}$ [1]. Gasification systems typically have electrical efficiencies of $18-33 \%$ [26], similar to those of decentralised power plants, with the typically engine operated TwoStage gasifier of 29\% (gross) [17]. Two of the most efficient 
demonstrated biomass gasification systems, not using fuel cells, are the Värnamo combined cycle and Skive engine plants. These plants reach electrical efficiencies of 33\% and $30 \%$ respectively $[27,28]$ and are significantly outperformed in comparison to these tests.

\subsection{Long-term performance of SOFC stack}

In order to investigate any decline in the performance of the SOFC stack when continuously using product gas, the results of the 62 hour-test (Test 5) have been used. During the test, the gasifier stopped for 1 hour due to a fuel feeding fault and the SOFC stack was consequently stopped. The SOFC stack did however assume full-load operation at 20.1 A again after 2.5 hours after the stop. The performance of the stack is shown as stack voltage on Figure 8 and key data are presented in Table 6.

The SOFC operation during the 62 hours was generally stable throughout the test, with power fluctuating within $\pm 10 \mathrm{~W}$, which is to be expected with slightly varying gas flow and composition (see Figure 4). As seen in Figure 8 and as mentioned earlier, the voltage did however experience some spikes during operation, which is likely caused by droplets that are carried over from the humidifier and in turn evaporates when reaching the heat exchangers. The sudden evaporation will cause the local steam concentration to increase and lower the heating value of the gas locally, which decreases the stack voltage. The drop in voltage was very short and voltage was stabilized quickly after.

In order to assess the SOFC performance, the voltage is calculated independently of product gas fluctuations as these will affect the voltage. By evaluating the stacks overpotential using the Nernst equation, the internal losses can be assessed. The data for Test 5 is divided into sections of 30 minutes that are averaged. The overpotential $V_{O P}$ can then be calculated as in 
Equation 4 from the measured voltage, $V_{\text {exp }}$, using the Nernst equation [22], assuming complete steam reforming of $\mathrm{CO}$ and $\mathrm{CH}_{4} . E^{0}$ is the electrode potential at standard conditions for hydrogen and $P$ is the average partial pressure of the product gas in the stack. $P_{H 2-e q}$ is the accumulated partial pressures of $\mathrm{H}_{2}, \mathrm{CO}$ and four times $\mathrm{CH}_{4}$ as in Equation 1.

It can be challenging to model a precise SOFC performance using a zero-dimensional model as chosen here. Multiple factors as varying temperature, gas composition, and pressure across the electrode structure causes relatively simple models to rely on estimates. This is discussed by Bang-Møller [24], where the approach taken here with Equation 4 is evaluated against a more precise form, which caused the Nernst and cell voltage to be $4 \%$ and $19 \%$ lower respectively at similar conditions. However, as the calculations of this project focuses on a trend in voltage and because the gas composition is very stable (see Figure 4), the error in modeling will only affect the trend to a minor degree.

$$
V_{\text {exp }}=\left(E^{0}-\frac{R \cdot T}{2 \cdot F} \ln \left[\frac{P_{H 2 O}}{P_{H 2-e q} \cdot P_{O 2}}\right]-V_{O P}\right) N_{c}
$$

The calculated overpotential for the SOFC stack is shown in Figure 9. The value fluctuates slightly, which is due the discussed modeling assumptions above and to minor disturbances in the system, namely the gas pump was found to fluctuate. The overpotential of the stack is split into two sections: before and after the 2.5 hour fall-out. Before, the overpotential is increasing at a low rate, indicating that the stack performance is declining. After the stop, however, the overpotential is stable, but with a higher value, indicating that the stack has been damaged by the sudden stop in operation. This effect is likely due to the thermal cycling that the SOFC experiences during the sudden stop in operation - the SOFC control was designed to shut off power when the gasifier stopped, meaning that the current went from $20.1 \mathrm{~A}$ to $0 \mathrm{~A}$ in an 
instance. This immediate shut-down, can decrease the contacting between electrodes and electrolyte/interconnect and hence increase losses as the remaining contact sites are forced to increase load, resulting in increased overpotential - this phenomenon is discussed in e.g. [29]. Hence, future tests should implement a revised control strategy that gradually lowers the drawn current from the stack in order to limit degradation. Following the stop, the continuous operation with product gas did not affect the stack after the stop. As the test showed some increase in overpotential before the stop and constant operation after, there is not enough data to conclude whether long-term operation is feasible and longer tests are recommended.

In all, a total of 145 hours of operation was however carried out on product gas, without significant decline in SOFC performance that indicates loss of performance when combining these two technologies. However, two aspects should be kept in mind when evaluating these results: 1) the stack performance has not been tested before and after the tests with a reference gas, so specifics on a possible performance decline has not been investigated - for instance could the high fuel utilization have caused a decline in performance that cannot be assessed over the operating time of this project; 2) the stacks initial condition is unknown by Topsoe Fuell Cell and the stack might have decreased performance compared to an unused stack. Following the test campaigns, the gas separation of the stack was tested at room temperature with gas tracing and it was found that there was a leak between anode and cathode, which will lead to either anode oxidation and/or loss of fuel, but in all cases a loss of performance.

\subsection{Comparison with modeling studies}

Within the BioSOFC project, the coupling of the TwoStage gasifier and SOFC's has been studied by mathematical modeling in other publications $[5,6,7,8,24,30,31]$. The main results from these publications are discussed here in relation to the experimental data and the system 
potential.

The TwoStage-SOFC system is projected as a decentralised plant with capacities below $10 \mathrm{MW}_{\mathrm{e}}$. The system were modeled to have an electrical efficiency of $44.9 \%$ with a FU of $85 \%$ [5], which is within range of the results presented here. The modeled results for the SOFC fit well with the obtained experimental results in e.g. [5].

However, as the SOFC is subject to a certain FU, there are high quality heat and excess fuel available downstream that can heighten the system efficiency. Therefore, combined cycle (CC) concepts that enhance the electrical efficiency have been modeled. The efficiencies for various CC configurations are shown in Table 7, showcasing the very high potential of decentralised power based on biomass gasification and SOFC technologies. The results stress the need to utilize the SOFC off-gases in order to be as competitive on efficiency as possible and design some of the most efficient systems available. Downstream power generation could also be implemented as a cost reduction measure as lower FU also leads to lower maintenance costs of the SOFC.

Thermoeconomic studies were also included in $[8,30]$. Both studies concluded that the main expense of the system is the investment cost. Specifically the SOFC capital cost was found to be the main bottleneck for commercialization. Electricity prices were found to be close to competitive with other biomass power generation, but not sufficiently high to justify the high investment. Thus continued technology maturation and SOFC cost reduction will be needed if the plant will be competitive without incentives.

\section{CONCLUSIONS}

Experimental studies were performed on an $800 \mathrm{~W}_{\mathrm{e}} \mathrm{SOFC}$ stack, operated on real product gas from the TwoStage gasifier. The test setup featured the TwoStage biomass gasifier, the SOFC 
stack and simple gas cleaning consisting of only a bag filter, two carbon filters, a humidifier and a desulphuriser. No tar could be detected. Only small amounts of sulphur compounds were found, enabling both the carbon filters and desulphuriser to remove them, which can reduce complexity even further. Thus the TwoStage gasifier is very well suited for operating SOFC with only a minimum of gas conditioning.

The SOFC was operated at $700^{\circ} \mathrm{C}$ and was subject to 4 tests with different flows from $15-28$ 1/min and currents from 0-24.1 A for up to 62 hours. The 4 tests displayed the SOFC stacks excellent part-load performance down to 55\% flow, without loss of efficiency. The tests achieved the highest reported values of such a system globally, with a SOFC stack electric efficiency of $46.4 \%$ at $90 \%$ fuel utilisation. A gasifier-SOFC system electric efficiency was estimated to be around $40 \%$, which is considerably higher than those from traditional decentralised biomass power plants and showcases the systems intriguing potential. A total of 145 hours of operation was achieved without significant losses in SOFC performance.

\section{ACKNOWLEDGEMENTS}

The authors would like to thank the ForskEL- and ForskVE-programmes of Energinet.dk for financial support through the BioSOFC (ForskEL-10456) and Biomass Gasification Polygeneration (ForskVE-12205) projects. The authors would like to thank Topsoe Fuel Cell for delivering the SOFC stack and the DTU Energy department for technical assistance.

\section{REFERENCES}

[1] International Energy Agency, Technology Roadmap - Bioenergy for Heat and Power, (2012) 
[2] IPCC, Renewable energy sources and climate change mitigation: special report of the Intergovernmental Panel on Climate Change. (2012). Choice Reviews Online (Vol. 49). doi:10.5860/CHOICE.49-6309

[3] Danish Energy Agency. (2014). Energiscenarier frem mod 2020, 2035 og 2050.

[4] Ahrenfeldt, J., Thomsen, T. P., Henriksen, U., \& Clausen, L. R. (2013). Biomass gasification cogeneration - A review of state of the art technology and near future perspectives. Applied Thermal Engineering, 50(2), 1407-1417. doi:10.1016/j.applthermaleng.2011.12.040

[5] Bang-Møller, C., Rokni, M., Elmegaard, B., Ahrenfeldt, J., \& Henriksen, U. B. (2013). Decentralized combined heat and power production by two-stage biomass gasification and solid oxide fuel cells. Energy, 58, 527-537. doi:10.1016/j.energy.2013.06.046

[6] Pierobon, L., Rokni, M., Larsen, U., \& Haglind, F. (2013). Thermodynamic analysis of an integrated gasification solid oxide fuel cell plant combined with an organic Rankine cycle. Renewable Energy, 60, 226-234. doi:10.1016/j.renene.2013.05.021

[7] Rokni, M. (2012). Thermodynamic investigation of an integrated gasification plant with solid oxide fuel cell and steam cycles. Green, 2(2-3), 71-86. doi:10.1515/green-20110022

[8] Rokni, M. (2014). Thermodynamic and thermoeconomic analysis of a system with biomass gasification, solid oxide fuel cell (SOFC) and Stirling engine. Energy, 76, 19-31. doi:10.1016/j.energy.2014.01.106

[9] Hofmann, P., Schweiger, a., Fryda, L., Panopoulos, K. D., Hohenwarter, U., Bentzen, J. D., Kakaras, E. (2007). High temperature electrolyte supported Ni-GDC/YSZ/LSM SOFC operation on two-stage Viking gasifier product gas. Journal of Power Sources, 173(1), 357366. doi:10.1016/j.jpowsour.2007.04.073 
[10] Hofmann, P., Panopoulos, K., Fryda, L., Schweiger, a, Ouweltjes, J., \& Karl, J. (2008). Integrating biomass gasification with solid oxide fuel cells: Effect of real product gas tars, fluctuations and particulates on Ni-GDC anode. International Journal of Hydrogen Energy, 33(11), 2834-2844. doi:10.1016/j.ijhydene.2008.03.020

[11] Hofmann, P., Panopoulos, K. D., Aravind, P. V., Siedlecki, M., Schweiger, A., Karl, J., ... Kakaras, E. (2009). Operation of solid oxide fuel cell on biomass product gas with tar levels $>10$ g Nm-3. International Journal of Hydrogen Energy, 34(22), 9203-9212. doi:10.1016/j.ijhydene.2009.07.040

[12] Jewulski, J., Stepien, M., Blesznowski, M., \& Nanna, F. (2010). Slip stream testing with a SOFC unit at Güssing and Trisaia plants.

[13] Oudhuis, A. B. ., Bos, A., Ouweltjes, J. P., Rietveld, G., \& van der Giesen, A. . (2004). High efficiency electricity and products from biomass and waste, experimental results of proof of principle Presented at the 2nd World Conference and Technology Exhibition. In The 2nd world conference and technology exhibition on biomass for energy, industry and climate protection (pp. 10-14).

[14] Nagel, F. (2008). Electricity from wood through the combination of gasification and solid oxide fuel cells Systems analysis and Proof-of-concept, (17856). doi:10.3929/ethz-a005773119

[15] Henriksen, U., Ahrenfeldt, J., Jensen, T. K., Gøbel, B., Bentzen, J. D., Hindsgaul, C., \& Sørensen, L. H. (2006). The design, construction and operation of a $75 \mathrm{~kW}$ two-stage gasifier. Energy, 31(10-11), 1542-1553. doi:10.1016/j.energy.2005.05.031

[16] Gøbel, B., Henriksen, U., Ahrenfeldt, J., Jensen, T. K., Hindsgaul, C., Bentzen, J. B., \& Sørensen, L. H. (2003). Status - 200 Hours of Operation with The Viking Gasifier, 3-6. Retrieved from http://medcontent.metapress.com/index/A65RM03P4874243N.pdf 
[17] Ahrenfeldt, J., Henriksen, U. B., Jensen, T. K., Gøbel, B., Wiese, L., Kather, A., \&

Egsgaard, H. (2006). Validation of a continuous combined heat and power (CHP) operation of a Two-Stage biomass gasifier. Energy \& Fuels, 20, 2672-2680.

[18] Egsgaard, H., Ahrenfeldt, J., Ambus, P., Schaumburg, K., \& Henriksen, U. B. (2014).

Gas cleaning with hot char beds studied by stable isotopes. Journal of Analytical and Applied Pyrolysis, 107, 174-182. doi:10.1016/j.jaap.2014.02.019

[19] Aravind, P. V., \& de Jong, W. (2012). Evaluation of high temperature gas cleaning options for biomass gasification product gas for Solid Oxide Fuel Cells. Progress in Energy and Combustion Science, 38(6), 737-764. http://doi.org/10.1016/j.pecs.2012.03.006

[20] Gadsbøll, R., Thomsen, J., Bang-Møller, C., Ahrenfeldt, J., Henriksen, U. (2015). Experimental analysis of solid oxide fuel cell coupled with biomass gasification. Proceedings of the conference. 2015 European biomass conference and exhibition,555-561

[21] Rostrup-Nielsen, J. R., Hansen, J. B., Helveg, S., Christiansen, N., \& Jannasch, a.-K. (2006). Sites for catalysis and electrochemistry in solid oxide fuel cell (SOFC) anode. Applied Physics A, 85(4), 427-430. http://doi.org/10.1007/s00339-006-3702-1

[22] Braun, R. J. (2002). Optimal Design and Operation of Solid Oxide Fuel Cell Systems for Small-scale Stationary Applications. PhD thesis, University of Wisconsin-Madison.

[23] Larminie, J., \& Dicks, A. (2003). Fuel cell systems explained (2nd ed.). John Wiley \& sons Ltd.

[24] Bang-Moeller, C. (2010). Design and Optimization of an Integrated Biomass Gasification and solid oxide fuel cell system. $\mathrm{PhD}$ thesis, Technical university of Denmark. [25] Basu. (2013). Biomass Gasification, Pyrolysis and Torrefraction (Second Ed.). Dalhouse University. 
[26] Quaak, P., Knoef, H., \& Stassen, H. (1999). Energy from Biomass a review of combustion and gasification technologies. World Bank Technical Paper, (422), 1-78. doi:ISBN0 -8213-4335-

[27] Knoef, H. (1 ${ }^{\text {st }}$ Ed.). (2005). Handbook Biomass Gasification, BTG biomass technology group.

[28] Ridjan, I., Mathiesen, B. V., \& Conolly, D. (2013). A review of biomass gasification technologies in Denmark and Sweden.

[29] Greco, F., Nakajo, A., Wuillemin, Z., \& Van herle, J. (2015). Thermo-Mechanical Reliability of SOFC Stacks during Combined Long-Term Operation and Thermal Cycling. ECS Transactions, 68(1), 1921-1931. http://doi.org/10.1149/06801.1921ecst

[30] Mazzucco, A., \& Rokni, M. (2014). Thermo-economic analysis of a solid oxide fuel cell and steam injected gas turbine plant integrated with woodchips gasification. Energy, 76, 114-129. doi:10.1016/j.energy.2014.04.035

[31] Pierobon, L., \& Rokni, M. (2014). Thermodynamic Analysis of an Integrated Gasification Solid Oxide Fuel Cell Plant with a Kalina Cycle. International Journal of Green Energy, 12(6), 610-619. doi:10.1080/15435075.2013.867267

lectricity exhaust gas

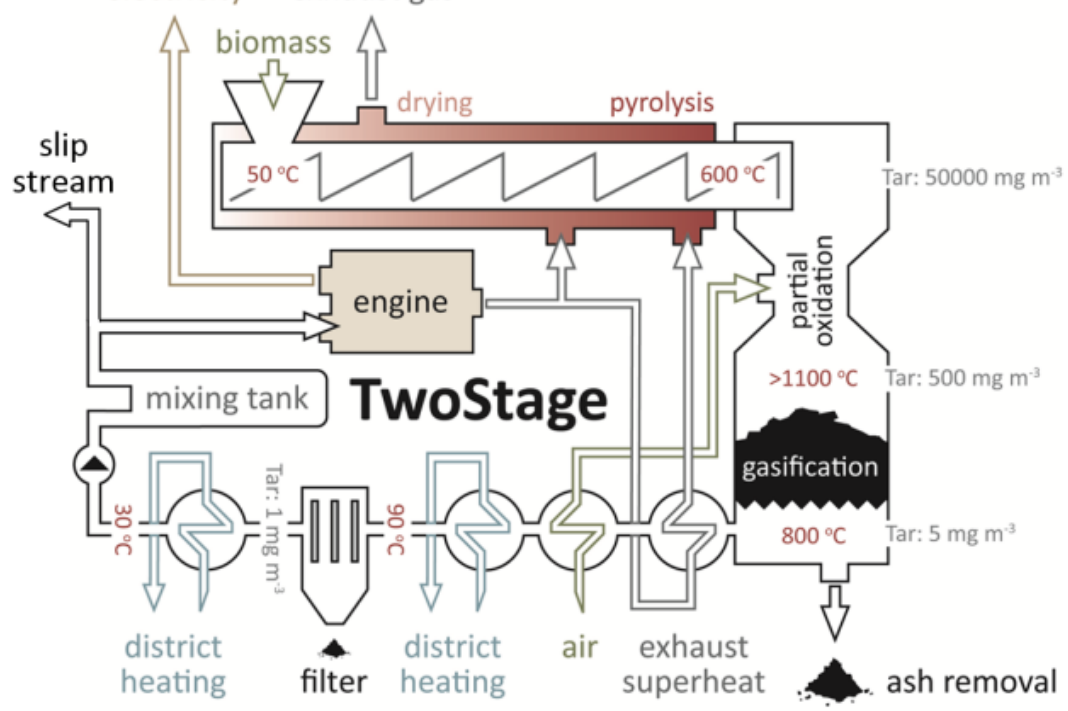


Figure 1: Flow diagram of TwoStage gasification with an engine.

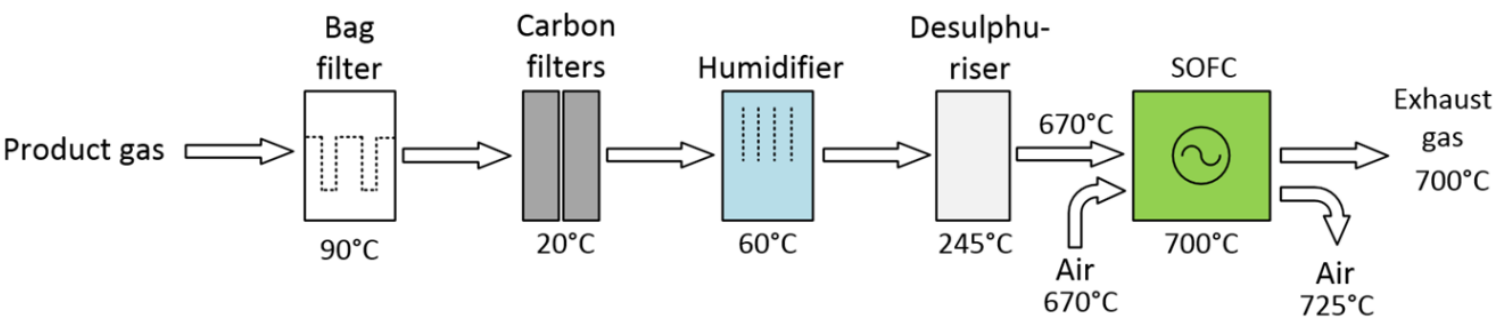

Figure 2: Overview of fuel cell gas conditioning with approximate operating temperatures.

Electric heaters are not shown.

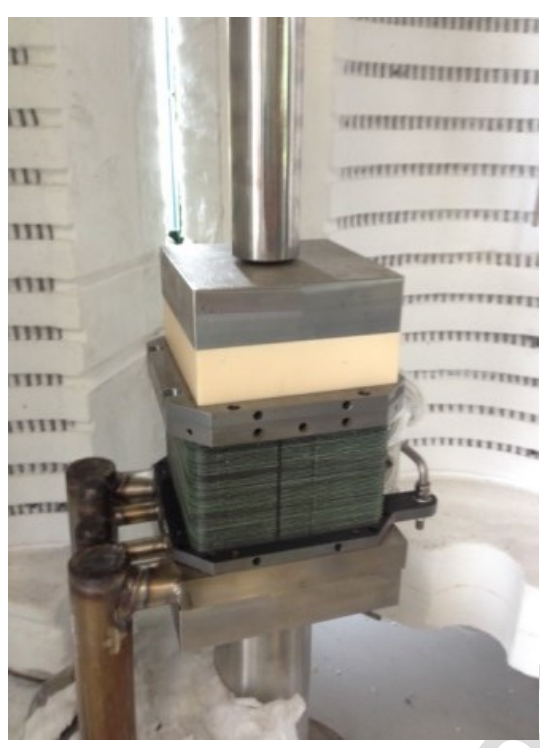

Figure 3: SOFC stack mounted in oven

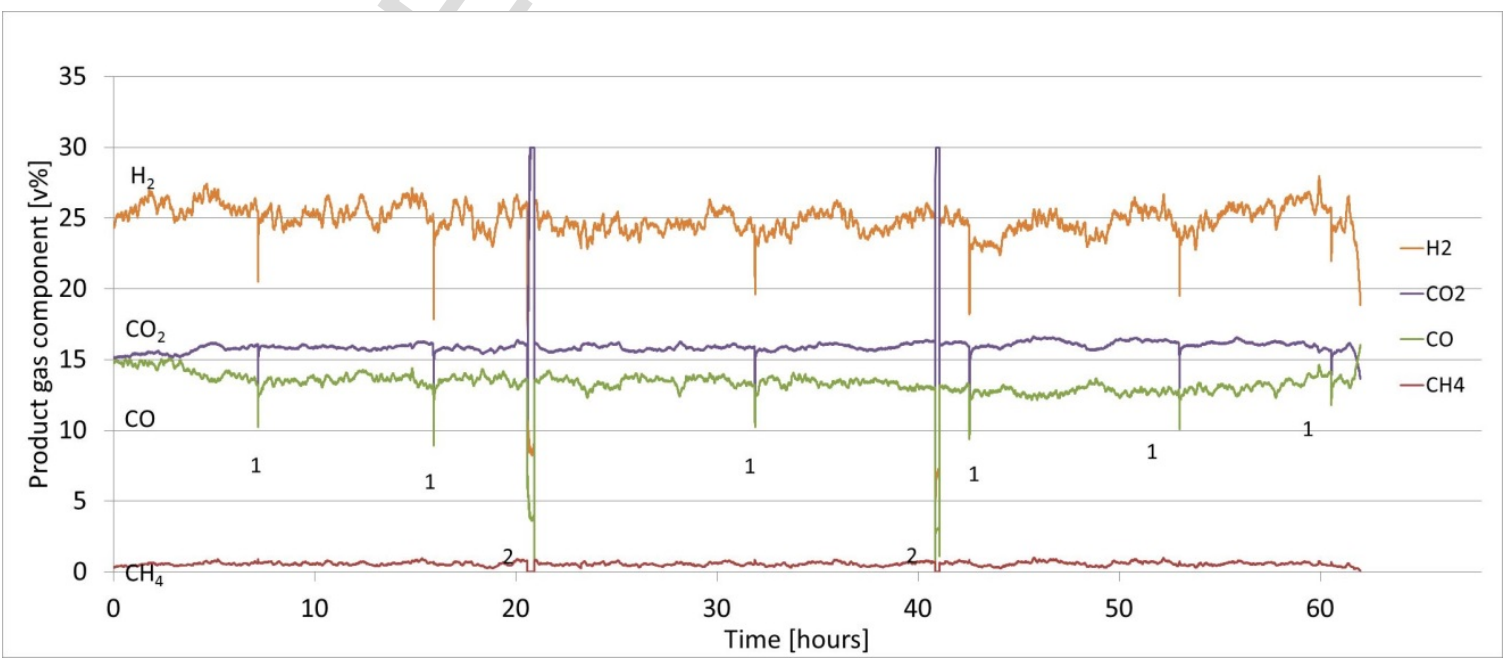


Figure 4: Gas composition during Test 5 for 62 hours. Incidents marked '1' are during flushing of the bag filter and '2' are measurements of SOFC exhaust.

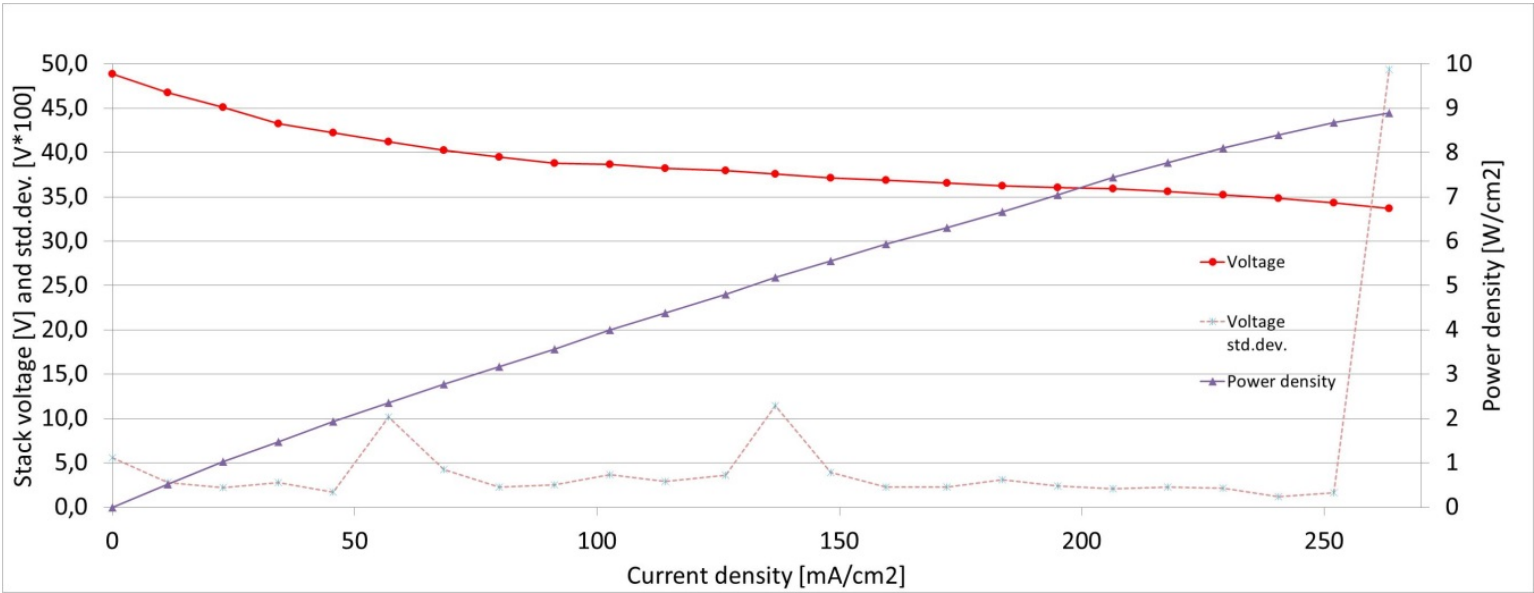

Figure 5: SOFC stack voltage with standard deviation and power density shown as a function of current density for Test 2.

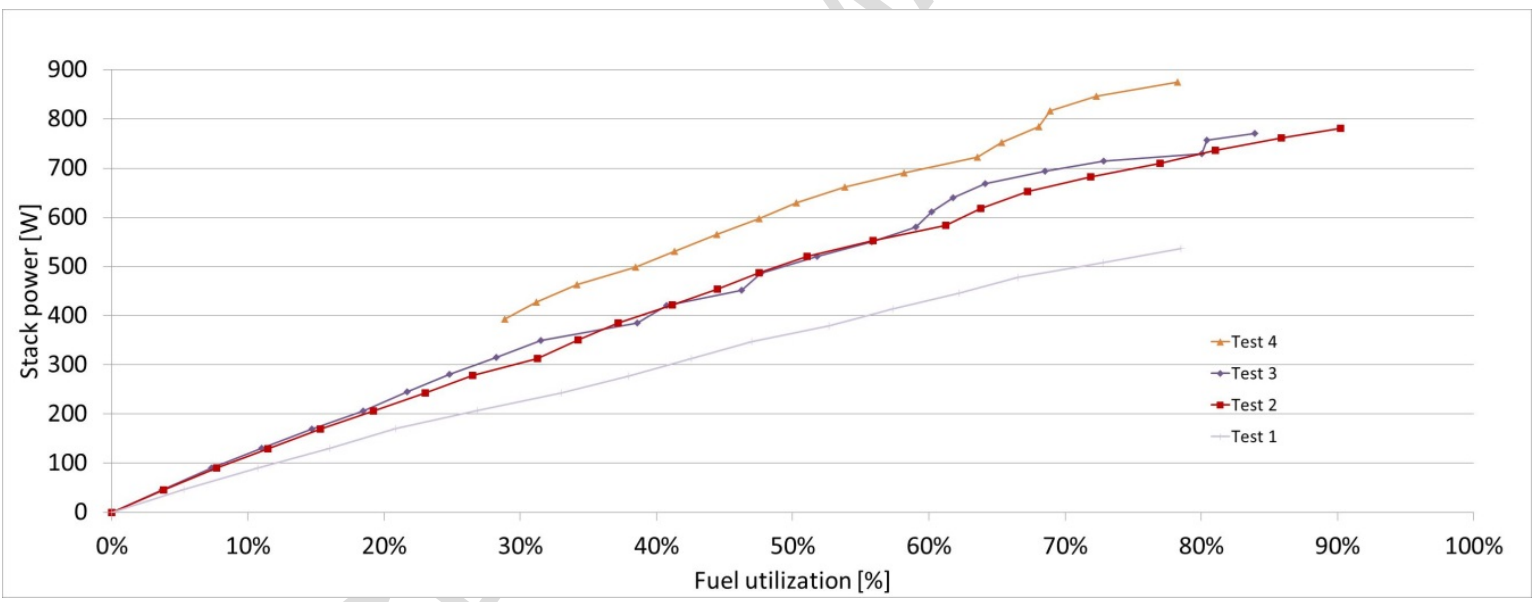

Figure 6: SOFC stack power output shown as a function of fuel utilisation for Test 1-4. 


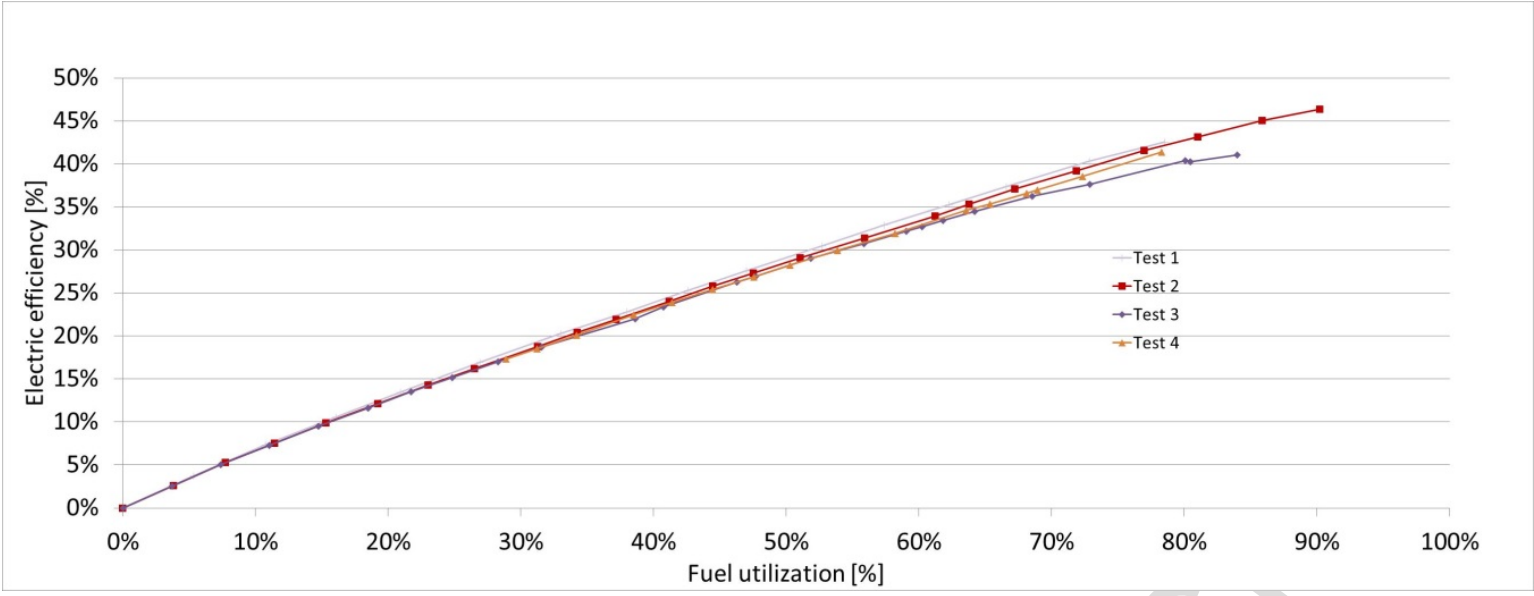

Figure 7: SOFC stack electric efficiencies shown as a function of fuel utilisation for Test 1-

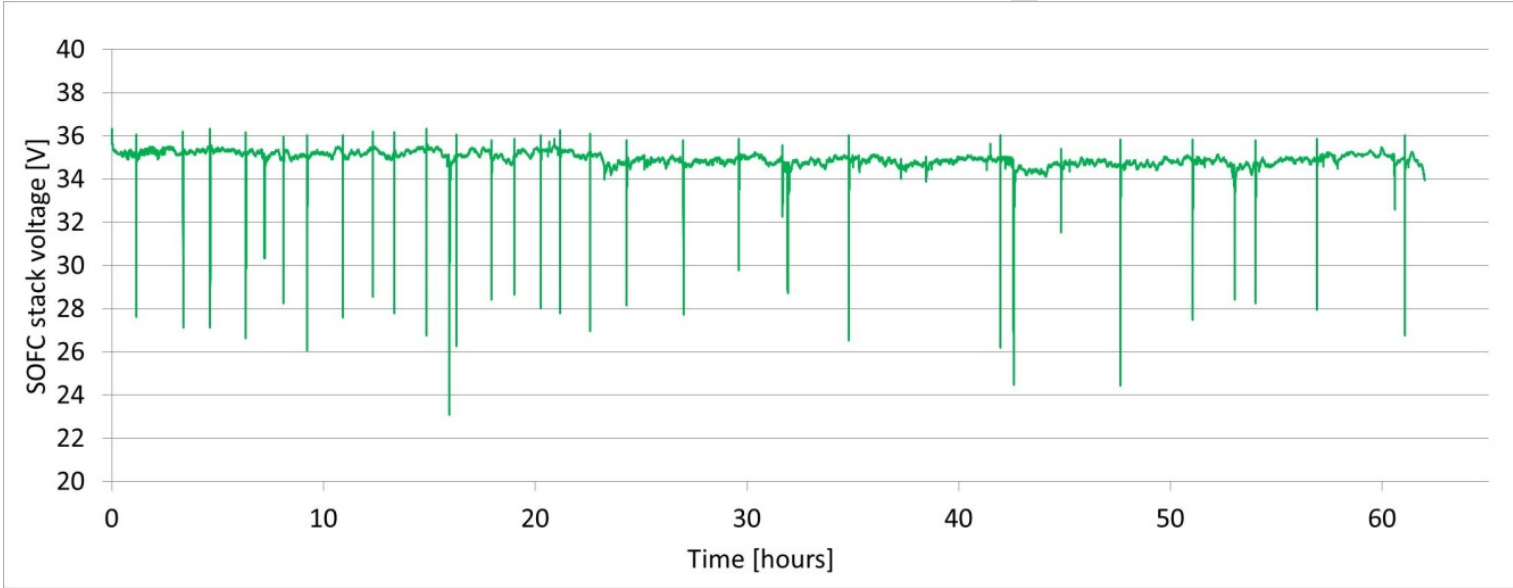

Figure 8: SOFC stack voltage during Test 5 for 62 hours. Spikes are caused by sudden pressure increases upstream of the SOFC. A stop of 2.5 hour is marked, but not shown. 


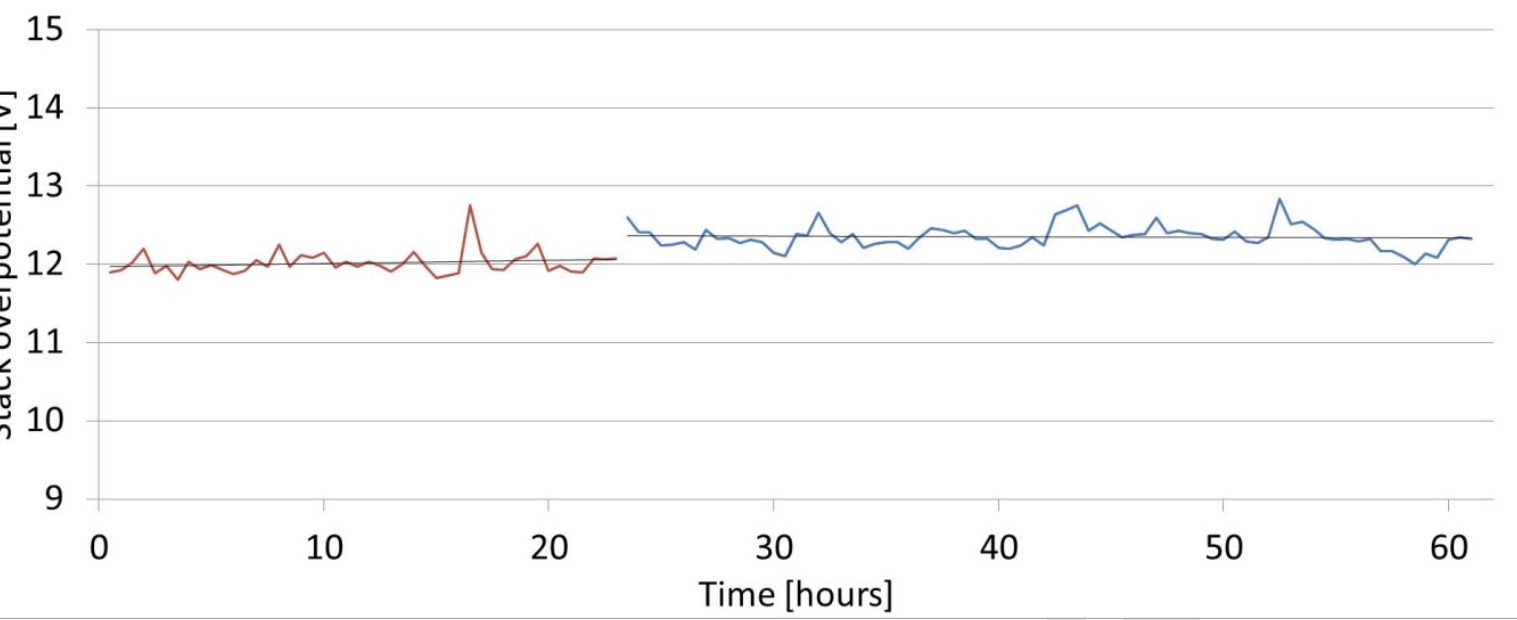

Figure 9: Overpotiential, $V_{O P}$ during Test 5 for 62 hours, as described by Equation 4 . The curve is split where there was a 2.5 hours stop in operation. Trendlines are added for each curve.

\begin{tabular}{|l|c|c|c|}
\hline Component & Method & Measure 1 & Measure 2 \\
\hline Ash [wt\%, dry] & $550^{\circ} \mathrm{C}$, app. 20h & - & - \\
\hline HHV [MJ/kg, dry] & ISO 1928 & 19.60 & - \\
\hline LHV [MJ/kg, dry] & ISO 1928 & 18.28 & 49.00 \\
\hline C (wt\%, dry) & ASTM 5373 & 48.90 & 6.00 \\
\hline H (wt\%, dry) & ASTM 5373 & 6.20 & 0.40 \\
\hline N (wt\%, dry) & ASTM 5373 & 0.17 & 0.07 \\
\hline S (wt\%, dry) & ASTM 4239C & 0.022 & - \\
\hline Cl (wt\%, dry) & ASTM 4208, IC & 0.063 & 44.00 \\
\hline O (wt\%, dry) & - & - & 32.20 \\
\hline Moisture (wt\%) & - & - & \\
\hline
\end{tabular}

Table 1: Fuel measurements of wood chips from previous tests with the Viking gasifier [17] 


\begin{tabular}{|l|l|l|l|}
\hline Test \# & $\begin{array}{l}\text { Gas flow* } \\
{[1 / \mathrm{min}]}\end{array}$ & $\begin{array}{l}\text { Duration } \\
{[\text { hours }]}\end{array}$ & $\begin{array}{l}\text { Range of current values for tests } \\
{[\mathrm{A}]}\end{array}$ \\
\hline 1 & 15.9 & 1.5 & $0-15.1$ \\
\hline 2 & 22.5 & 3.5 & $0-23.1$ \\
\hline 3 & 23.0 & 7 & $0-24.1$ \\
\hline 4 & 28.8 & 2 & $10.0-25.1$ \\
\hline 5 & 22.4 & $62^{* *}$ & 20.1 \\
\hline
\end{tabular}

Table 2: Overview of tests performed. *Flow measured at $20^{\circ} \mathrm{C}$ and atmospheric pressure.

**Test 5 were stopped for 2.5 hours due to a 1-hour gasfier failure during the test.

\begin{tabular}{|c|c|c|c|c|c|c|c|}
\hline Test \# & $\begin{array}{l}\mathrm{CH}_{4} \\
{[\mathrm{vol} \%]}\end{array}$ & $\begin{array}{l}\mathrm{CO} \\
{[\mathrm{vol} \%]}\end{array}$ & $\begin{array}{l}\mathrm{CO}_{2} \\
{[\mathrm{vol} \%]}\end{array}$ & $\begin{array}{l}\mathrm{H}_{2} \\
{[\mathrm{vol} \%]}\end{array}$ & 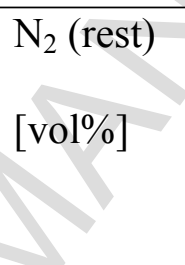 & $\begin{array}{l}\text { Sum } \\
{[\mathrm{vol} \%]}\end{array}$ & $\begin{array}{l}\text { Gas energy flow } \\
(\mathrm{LHV})^{*} \\
{[\mathrm{~W}]}\end{array}$ \\
\hline 1 & 0.6 & 15.2 & 15.4 & 27.2 & 41.6 & 100.0 & 1245 \\
\hline 2 & 0.7 & 14.1 & 15.1 & 26.3 & 43.8 & 100.0 & 1723 \\
\hline 3 & 0.7 & 15.6 & 14.1 & 26.7 & 42.8 & 99.9 & 1826 \\
\hline 4 & 0.5 & 14.9 & 15.3 & 26.0 & 43.3 & 100.0 & 2200 \\
\hline 5 & 0.6 & 13.3 & 16.0 & 24.8 & 45.3 & 100.0 & 1588 \\
\hline
\end{tabular}

Table 3: Overview of average dry product gas compositions during the different tests.

Compositions are calculated as average values over 3-10 minutes. Nitrogen content is during the experiment

\begin{tabular}{|l|l|l|l|l|}
\hline Test & Product gas & Exhaust & Air in & Air out \\
$\#$ & {$\left[{ }^{\circ} \mathrm{C}\right]$} & gas $\left[{ }^{\circ} \mathrm{C}\right]$ & {$\left[{ }^{\circ} \mathrm{C}\right]$} & {$\left[{ }^{\circ} \mathrm{C}\right]$} \\
\hline
\end{tabular}




\begin{tabular}{|l|l|l|l|l|}
\hline 1 & $658-666$ & $676-688$ & $657-668$ & $684-711$ \\
\hline 2 & $649-670$ & $672-698$ & $654-671$ & $680-732$ \\
\hline 3 & $650-670$ & $675-700$ & $655-675$ & $680-730$ \\
\hline 4 & $651-682$ & $687-706$ & $663-675$ & $700-733$ \\
\hline 5 & $661-683$ & $691-705$ & $663-677$ & $719-731$ \\
\hline
\end{tabular}

Table 4: Gas temperature measurement ranges during tests in and out of the SOFC stack

caused by changes in load and gas compositions.

\begin{tabular}{|l|l|l|l|l|}
\hline $\begin{array}{l}\text { Test } \\
\#\end{array}$ & $\begin{array}{l}\text { Flow compared to Test 4 } \\
{[\%]}\end{array}$ & $\begin{array}{l}\text { Power } \\
{[\mathrm{W}]}\end{array}$ & $\begin{array}{l}\text { Electric efficiency } \\
{[\%]}\end{array}$ & FU [\%] \\
\hline 1 & 55.2 & 537 & 42.6 & 78.5 \\
\hline 2 & 78.1 & 780 & 46.4 & 90.2 \\
\hline 3 & 79.9 & 771 & 41.0 & 84.0 \\
\hline 4 & 100 & 875 & 41.4 & 78.3 \\
\hline
\end{tabular}

Table 5: Data for max fuel utilisation (FU) measurements. Data are taken as averages over 60 $\min$.

\begin{tabular}{|l|l|l|l|l|}
\hline $\begin{array}{l}\text { Gas flow* } \\
{[1 / \mathrm{min}]}\end{array}$ & $\begin{array}{l}\text { Current } \\
{[\mathrm{A}]}\end{array}$ & $\begin{array}{l}\text { Power } \\
{[\mathrm{W}]}\end{array}$ & $\begin{array}{l}\text { Electric efficiency } \\
{[\%]}\end{array}$ & $\begin{array}{l}\text { FU } \\
{[\%]}\end{array}$ \\
\hline 22.4 & 20.1 & $704 \pm 9.8$ & 44.3 & 83.0 \\
\hline
\end{tabular}

Table 6: Key data for Test 5 taken as an average over 62 hours with standard deviation for power as primary measurement. ${ }^{*}$ Gas flows are measured at $20^{\circ} \mathrm{C}$ and atmospheric pressure. 


\begin{tabular}{|l|l|l|}
\hline & {$\left[\mathrm{MW}_{\mathrm{e}}\right]$} & {$[\%]$} \\
\hline SOFC [5] & 1.4 & 44.9 \\
\hline SOFC-Stirling engine [8] & 0.12 & 42.4 \\
\hline SOFC-Organic rankine cycle [6] & 0.1 & $54-62$ \\
\hline SOFC-Gas turbine [24] & 0.3 & $55-58$ \\
\hline SOFC-Kalina cycle [31] & 8 & $49-58$ \\
\hline SOFC-Steam cycle [7] & 10 & $48-56$ \\
\hline SOFC-Steam injected gas turbine [30] & 10 & $48-50$ \\
\hline
\end{tabular}

Table 7: Main results of modeling studies with TwoStage gasifier, SOFC and further downstream power generation. 